\title{
«Image» as an Instrument of Urban Management
}

\section{Andrea Kampschulte, Basel}

\section{Introduction}

Ever more cities rely on urban marketing concepts to attract investment, industry and tourism. The neglected urban population needs to be recognized and addressed in order to prevent further de-urbanization. Comprehensive, holistic strategies proposing a long-term vision and clear development goals, should address and involve all sectors in the marketing process (KONKEN 1996: 9). Fundamental to such a market-orientated public policy for urban development is a status quo survey and analysis of the image of the city. Potential image problems and possible solutions can thus be revealed.

Presented here are the results of an image study made in Basle in 1997 (KampSChulte, SCHNEIDER-Sliwa 1999). Opening with a short description of the effects of globalization on entrepreneurial urban policy and of the increasing importance of city images in general, the paper focuses on the attractiveness of Basle for the local population, tourists, visitors and local businesses. Clear conclusions for remodeling and improving the image of Basle emerge. Finally, the importance of an image study for the design of a holistic urban development strategy is explained.

\section{The «entrepreneurial» city}

Global social-economic restructuring, and the increasing international division of labor have given rise to competitiveness between urban areas. To attract investment and jobs, cities sell themselves as private enterprises. Current urban policy and modern municipal authorities not only govern the cities but also actively manage the processes of restructuring and inducing economic growth. By adopting marketing principles, the "product city» is sold with gain (KRÄTKE 1995: 246). As such, market-orientated public policies interpret urban management or marketing as a long-term strategy for urban development. All sectors within a city (inhabitants, businesses, tourists, visitors, investors, interest groups, non-profit organizations and political parties) are involved (KotLer, Haider \& REIN 1994: 34ff, KURON 1997: 3).

Discourse between cities with comparable local factors has emerged. The importance of the image of the city as a unique «selling point» is increasing (BEYROW 1998: 15). Besides the impact of global economic developments at a local level, image aspects need to be ad- dressed. In general, the commercial sector orientates itself toward the needs and demands of the "consumer». The marketing strategy aims to satisfy the consumer (BORCHERT 1994: 417). The main target groups (residents, tourists, visitors and local enterprises) exercise varying demands and expectations of the city. Differing living conditions, for example, give rise to varying needs within the population.

In short, the attractiveness of the city (standard of living, work and recreation) is the decisive factor. Increasing sub-urbanization verifies the diminishing attractiveness of cities, especially for families with children. Consequently, the elderly, the poor, the unemployed, foreigners, singles and single parents remain predominantly behind. Not only does the city lose important taxpayers, but is also faced with the emerging problem of social polarization. An integral, target-orientated strategy is essential for the analysis of image problems and for the development of concepts for remodeling existing images.

\section{Urban image and urban perception}

The improvement of urban image and identity is regarded as a suitable measure against decentralization, the exodus of taxpayers and the emerging social polarization. The image of the city is best described as the link between real, objective space and its perception. Decisions and actions taken in a city do not depend on the physical condition but rather on individual (subjective and selective) perception (SPIEgEL 1969: 29, Trieb 1974: 49). The perceiver determines the perception of the city (BEYROW 1998: 8). Varying social classes subjectively determine their choice of information, which, in turn, determines spatially relevant activities and their distribution. Urban perception manifests itself in positive or negative images of the city or parts thereof.

The image is an important component of the urban marketing concept, as it emphasizes the peculiarity and uniqueness of a city. The image communicates a distinct urban identity, which differs from other cities (HäUSSERmanN \& Siebel 1992: 29). A positive image enables the population to identify with his city, resulting in an improved outward image. Personal image and outward image contribute to the attractiveness of the city as perceived by residents, visitors and investors (KONKEN 1996: 35, 39). A positive image is thus of high economic value. A dissatisfaction of the city image may increase sub-urbanization. The local government relies on the image of the city as an indicator of successful urban policy (FUNKE 1994: 3). 


\section{Urban marketing as a strategy for urban development}

The attractiveness of a city is an important economic factor. The structure of a city, its architecture, minimal traffic, industrial diversity and recreational quality are factors that enhance the economic strength of the city. The city center especially demands improvement as it increasingly competes with peripheral locations. Dissatisfaction in the city center results in migration to the suburbs. Problems caused by economic restructuring, an over-aged urban population and the loss of valuable taxpayers have been mentioned above. Current opinion concerning the improvement of attractiveness and possible solutions to urban problems supports commercialism (DUDE 1989: 5ff). Flexible urban marketing is the local response to the dynamics of the global economic restructuring process. The «new» urban policy demands deregulation, private initiative and co-operation with private decision-makers in the form of public-privatepartnerships (HELBRECHT 1994: 43f).

Urban marketing is instrumental to managing integrated urban development today. It should thus not only be considered a means of advertising or campaigning to attract tourists and investors, but also a means of longterm management geared towards the needs and interests of existing customers (BERTRAM 1995: 29). Urban marketing aims to incorporate relevant target groups in a common comprehensive concept of the future development of the city. It is thus an ongoing communication process (KuRON 1997: 1). Urban development, economic improvement, the promotion of location and increasing attractiveness are essential to urban marketing. All activities aim to preserve and increase the content of internal (inhabitants, local business) and external customers (retail and service customers, investors, tourists). Partnership and the co-operation of relevant decision-makers are necessary requirements for a successful marketing strategy (MüLLER 1992: 2ff.). The marketing strategy usually consists of three successive steps: analysis (normative level), conception (strategic level) and implementation (operative level) (MEISSNER 1995: 23, Bertram 1995: 31 ff., Kuron 1997: 5ff.):

- A comprehensive status quo survey is required for the development of an urban marketing strategy, including an analysis of the image of the city among different target groups. A summary of the strengths and weaknesses of the city portrays its existing internal potential, forming the basis of opportunities or threats in the world of competition. The analysis should not be restricted to the location, but take into account exogenous factors as well.

- A long-term vision for the future development of the city is determined in the second phase. Strategic goals assigned to different stakeholders are included: economic development concepts, plans improving the city's attractiveness as perceived by the population, city-marketing concepts improving the attractiveness of the city center as well as destination marketing concepts for tourists and visitors. Popular participation ensures maximum identification with the marketing process. Urban marketing with a holistic approach is only possible under the leadership of public administration. The main task is to co-ordinate conflicting interests and to present possible solutions. At the end of the communication process, public administration defines clear development and urban marketing goals.

Strategies to improve the attractiveness are developed on the basis of a long-term vision and secondary goals. The target groups and competitors need to be identified. Local advantages and the uniqueness of each city should be emphasized to ensure distinction from other cities. A clear positioning on the «market» should be attempted (FrEY, SCHALTEGGER 1999: 6). Special measures concerning economic promotion, tourism, culture, traffic, social affairs and environment should be taken.

- The implementation of urban marketing measures is the domain and responsibility of public administration, whose task it is to give clear instructions. This phase includes the planning, organization and implementation of activities. Schedules, financial management and personal responsibilities need to be determined. At the end of the marketing process, control, new status quo analysis and, if need be, modification of existing strategies emerge.

Although the sequence of phases tends to be linear, integrated urban marketing is not only a long-term development concept, but also a permanent co-operative process. Continuous commitment and a general consensus of all persons involved are necessary. The «communicative competence» of a city is a key factor and vital requirement for nearly all phases of successful urban marketing (GRABOw 1998: 4).

\section{The Image of Basle}

\subsection{Empirical analysis objectives}

The outcome of an empirical investigation into the image of Basle is illustrated below. The objective of the survey was to establish the image of the city as perceived by varying target groups. Opinions concerning the attractiveness of Basle based on its standard of living, tourism and economic location are formulated. Three hypotheses were put forward:

1. The image of Basle varies according to target group:

- The personal image as perceived by inhabitants and local businesses differs from the outward image as perceived by tourists. 
2. The image as perceived by inhabitants varies according to place, time of residence, age and education:

- Inner-city dwellers or those living nearby perceive the image of the city distinctly differently to those living on the outskirts of the metropolitan area. The social-economic structure of districts in Basel-Stadt and of communities in Basel-Land influence that image too. The image of one's own district or community affects the image of the whole city.

- The relative importance of image factors varies with age (younger and older people perceive urbane quality differently)

- The level of education is a prerequisite for income differences. People with higher education and income, respectively, share differing interest and expectation of the city.

- Long-term residents of Basle perceive the city positively. With time, one is exposed to the strengths and weaknesses of a city, while subjective influences and emotional ties grow stronger. Those with a negative image of the city would presumably move out at some stage. Long-term residents are thus indicators of a positive image.

3. The image of Basle varies between subgroups of tourists (city tourists, (trade) fair visitors, congress participants), and within subgroups according to age, education and frequency of visits:

- Tourists who come to Basle for enjoyment (sightseeing, vacation, «art fair») differ in their perception of the city to those who visit for professional reasons (chemistry congress). The purpose of the visit deter- mines the type and range of activities pursued in Basle. One's first impression of the city, often forming the image, differs decisively among subgroups.

- Age and level of education affect the tourist's perception of the city.

- A positive image of the city is proportional to the frequency of visits. Visitors with a negative image of the city would refrain from returning. Repeated visits thus suggest a positive image.

During summer 1997, two method's classes in the Department of Geography at the University of Basle held 2015 interviews. Three target groups were selected: residents of the transborder metropolitan area of Basle, tourists (recreational and/or professional purposes) and «young» entrepreneurs (less than two years in Basle) (Table 1).

Besides proving the above mentioned hypotheses, the survey analyzed the following issues:

- How attractive is Basle?

- What are the major criteria for attractiveness?

- Does a common or a subtly differentiated image of the city exist?

- Do subjective perception and objective requirement have anything in common?

- Which (positive) image factors were overlooked?

- Which negative image factors exist?

- Where should one start to remodel the existing image?

\section{main group}

number of interviews

1010

local population

tourists

957

entrepreneurs

\section{total}

subgroup

number of interviews

by place of residence:

canton Basel-Stadt

425

canton Basel-Land

383

other cantons in Switzerland

Germany

101

France

unknown

507

332

trade-fair visitors («Art 28 '97»)

congress participants

(«Tenth European Symposium on

Organic Chemistry»)

firm location within the past two years

Tab. 1: Composition of the sample

Zusammensetzung der Stichprobe

Composition de l'échantillon

(Source: Kampschulte \& SchneIder-Sliwa 1999: 60) 


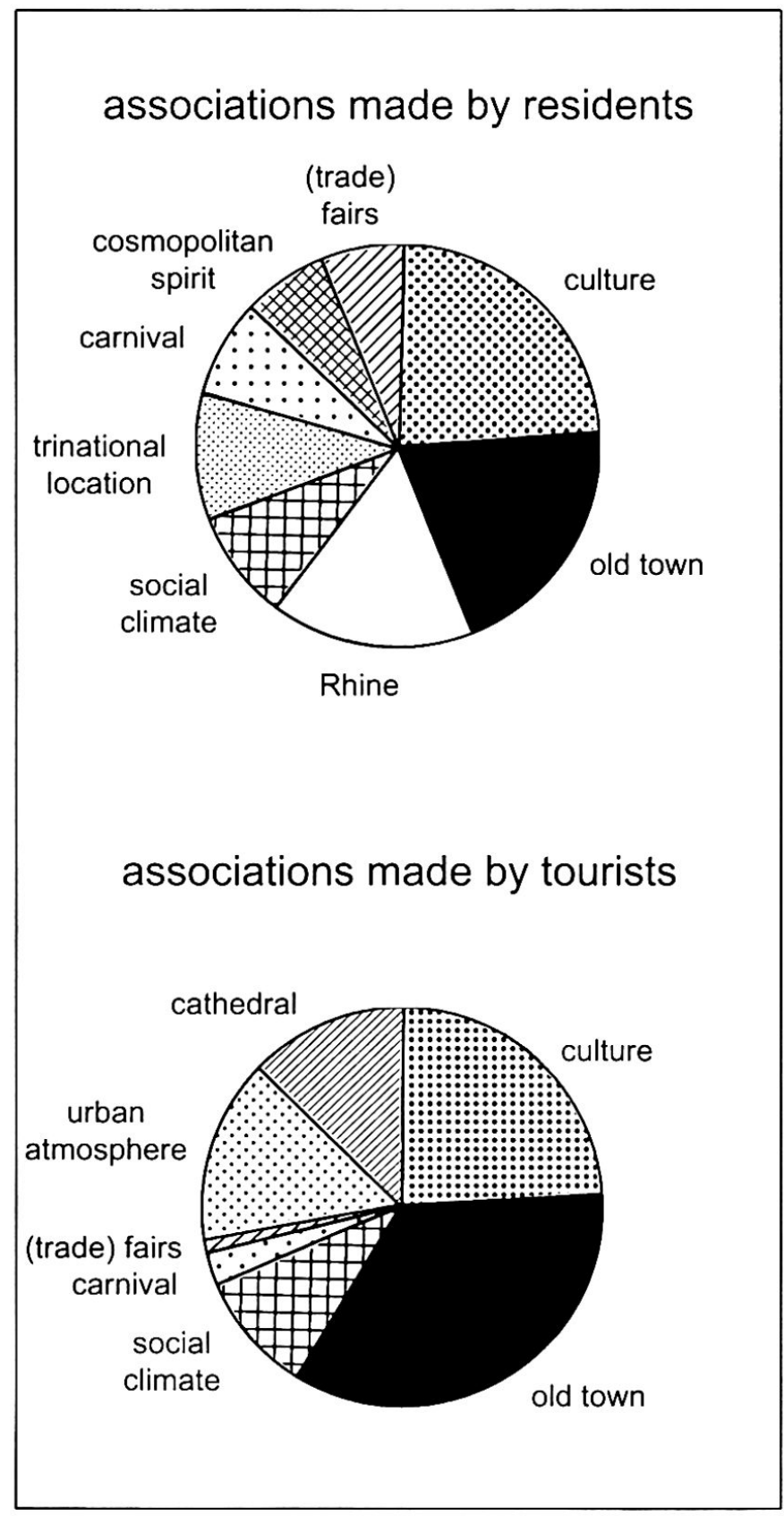

Fig. 1: Spontaneous associations made by residents and tourists

Spontane Assoziationen der Wohnbevölkerung und der Touristen

Associations spontanées de la population résidente et des touristes

(Source: Kampschulte \& SCHNEIDER-Sliwa 1999: 70, 85)

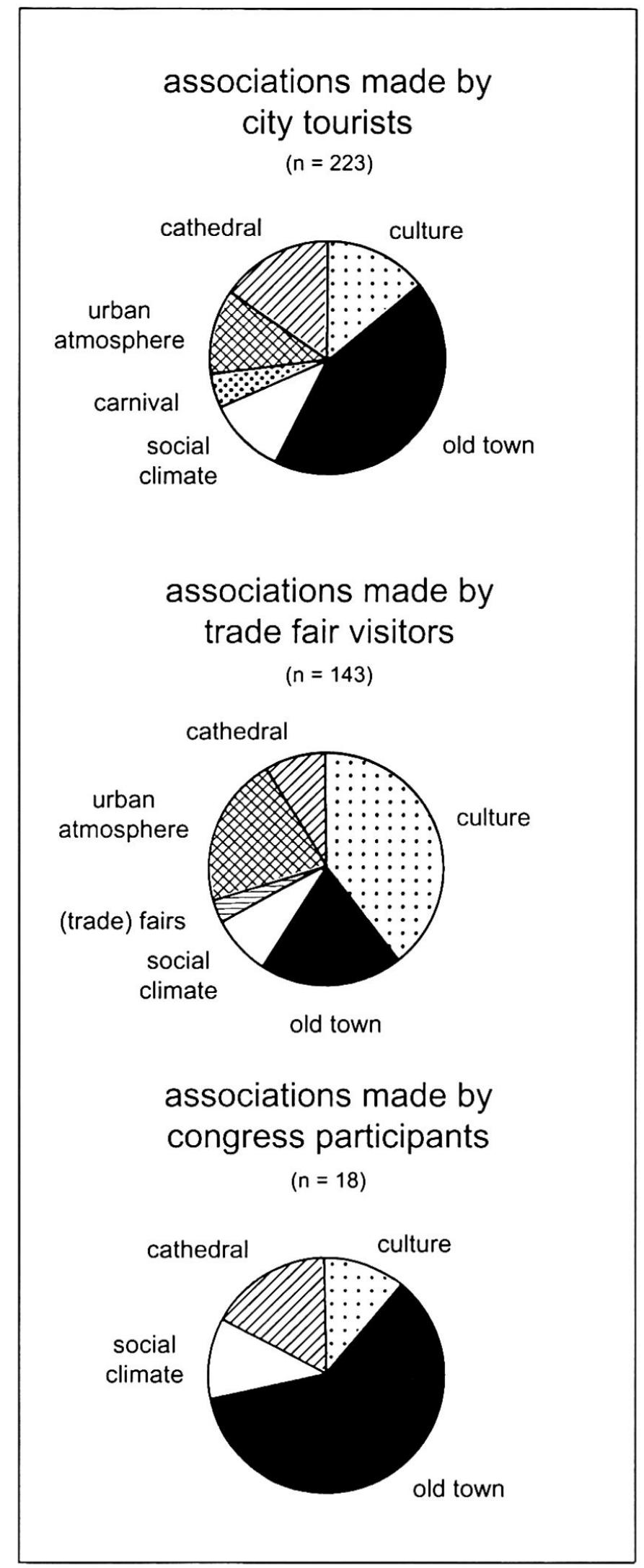

Fig. 2: Spontaneous associations made by tourist subgroups

Assoziationen der touristischen Teilgruppen Associations des sous-groupes de touristes (Source: Kampschulte \& SChNeider-Sliwa 1999: 85) 
Four main questions were posed:

1. In order to determine landmarks or special features of Basle, people were asked to share a spontaneous association with the city: What do residents and tourists intuitively connect with Basle?

2. In order to reveal personal perception of Basle's status and important for the comparison with other cities, the following question was asked: Which title characterizes the essence of Basle? The 6 titles were as follows: cultural city, city of fairs, city of sports, university city, industrial city and shopping city.

3. In order to analyze the attractiveness of Basle, the following features were discussed:

- Goods supply, social and medical institutions

- Recreational opportunities (culture, leisure-time, green/open space)

- Educational institutes

- Traffic situation (private/public).

4. In order to assess the attractiveness of Basle, semantic differentials were applied: Which of the 5 contrasting pairs apply to Basle: nice-ugly, narrow-minded-liberal-minded, interesting-boring, dirty-clean, cheap-expensive?

\subsection{Spontaneous associations: \\ Basle lacks a clear profile}

The survey proves the lack of a landmark that all residents of Basle identify to. The highest consensus is $18 \%$ and $17 \%$ respectively. Both residents and tourists associated Basle with culture $(18 \%$ and $11 \%)$ and the old town (15\% and $17 \%$ ) (Fig. 1). The Rhine was mentioned by $13 \%$ of the residents, while none of the tourists took notice of it.

The total amount of image factors was rather low, a number of which were barely $5 \%$. Attractions and special features including the cathedral, city hall, old city gates, fountains, museums, university and zoo were either not mentioned or only by very few. The tiny percentage allocated to culture and old town indicates the weakness of these image factors. Social climate, liberalminded society and atmosphere, factors elementary to the standard of living and housing, were found lacking entirely in the response from residents. This might indicate the general dissatisfaction of residents, resulting in migration from the city. The outcome of such movement could lead to further financial difficulties and social polarization, as mentioned before. The poor association is an indication of the diminishing attractiveness of the city as a place of residence.

Tourists do not associate Basle with the Rhine, the trinational place, the social climate nor humanistic tradition. The cathedral $(6 \%)$ is the only attraction in the city mentioned. The activity range of congress participants is limited to the narrow area between the congress center and hotel, limiting the tourist's visit to «lower Basle". More than $80 \%$ of those interviewed in this subgroup made no association with Basle at all. The rest of the group noted only four out of ten most frequently mentioned associations, including the old town (21\%) and the cathedral (6\%) (Fig. 2).

The image analysis confirms the theory that associations with Basle vary according to and within target groups. The target groups were thus analyzed more closely. The spontaneous associations of the residents depend on age, education and place of residence. The older generation, for example, associates Basle with the old town, while the younger generation makes mention of the tri-national place and Rhine. The latter has become a favorite meeting place for the youth. Higher-educated persons prefer cultural activities to spending time in the old town. A comparison of the prevailing images in different districts reveals the strong influence that the attractiveness and the perception of one's own district have on the city-image as a whole.

Depending on purpose and frequency of visits, tourists make different associations with Basle. The fair visitor is the only subgroup to consider Basle a trade fair center. Only $2 \%$ of the persons surveyed identified the fair at all. The «art», an international art fair, is predominantly regarded a cultural event, resulting in the low percentage of «fair» associations. This explains the above-average percentage of culture (19\%) in this subgroup. Vice-versa, only the city tourists make mention of the carnival (Fig. 2). The more frequent one visits Basle, the less important are the sights. Rather, cultural activities and urban atmosphere are of high priority. The commercialization of sights, cultural attractiveness and urban atmosphere are essential for sustaining tourism in Basle.

In summary, the following can be said:

- The image of Basle is fragile and needs sensitive improvement. Basle currently lacks a clear profile. Certain image factors should be selected and supported, such as the Rhine (significant urban element connecting upper and lower Basle) and the tri-national place (multicultural, liberal-minded).

- The «product» Basle needs to be marketed, with special emphasis placed on local features. Conflicting demands and behavior of subgroups should thus be better catered for. Measures should be taken to increase the awareness of congress participants, for example, about the cultural image of the city. The «mobility ticket» enables hotel guests free use of public transport and a better understanding of Basle.

- The cultural capital is an important image factor of Basle. In view of declining cultural expenses, the city should be aware that cultural tradition alone is not enough to preserve the cultural attractiveness of Basle. An active cultural promotion policy is necessary. 


\section{key words by residents}

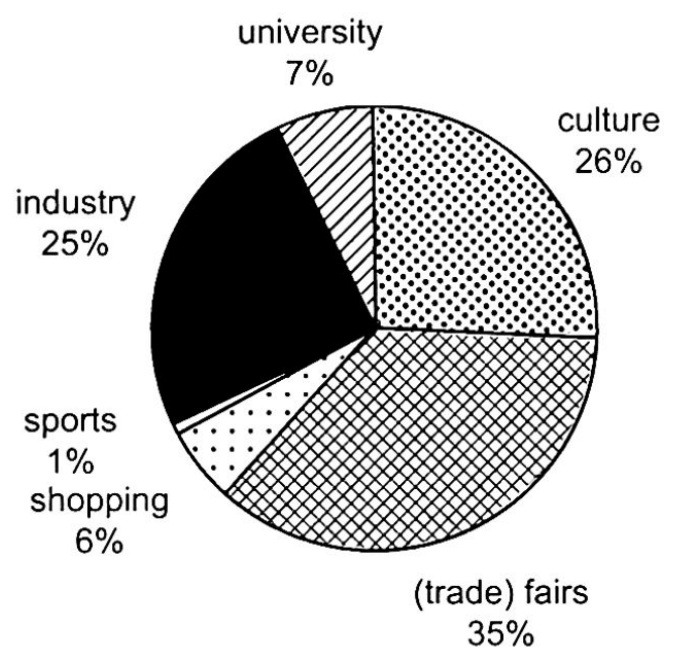

key words by tourists

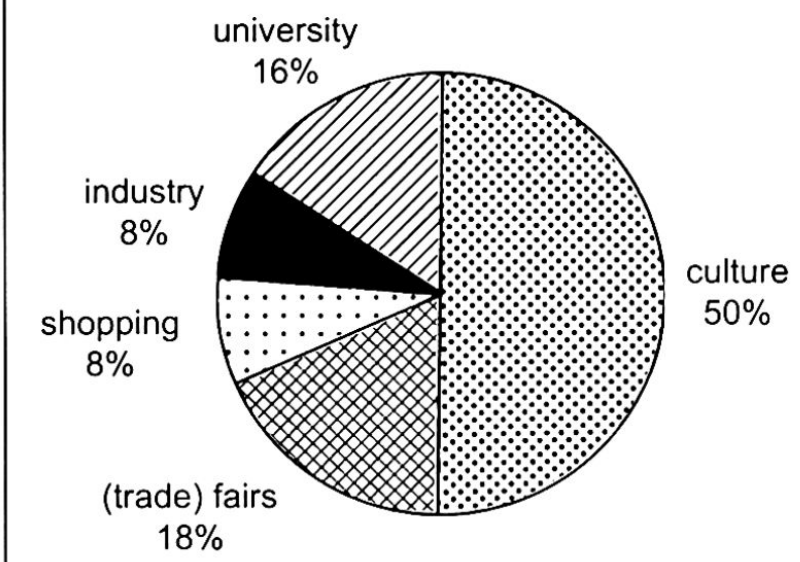

Fig. 3: Key words chosen by residents and tourists for characterizing Basle

Schlagwort zur Charakterisierung Basels:

Wohnbevölkerung und Touristen

Mot clé servant à caractériser Bâle:

population résidente et touristes

(Source: Kampschulte \& Schneider-Sliwa

1999: 75,89 )

\section{key words by city tourists}

$$
(n=170)
$$

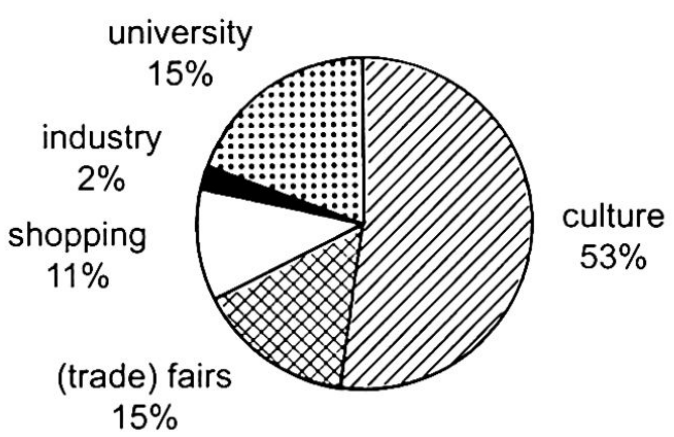

key words by trade fair visitors

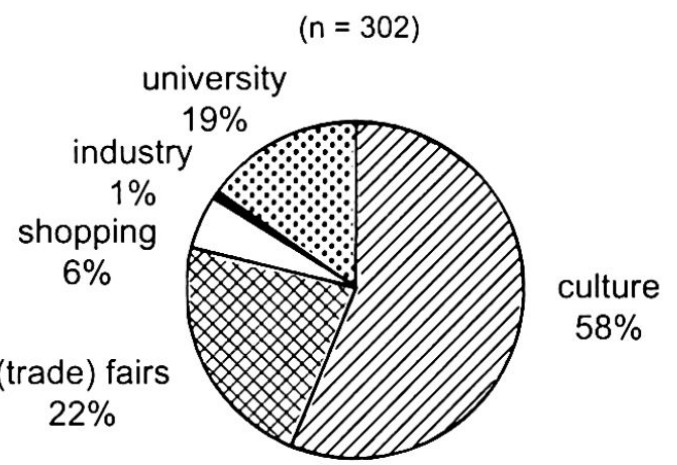

key words by congress participants

$$
(n=114)
$$

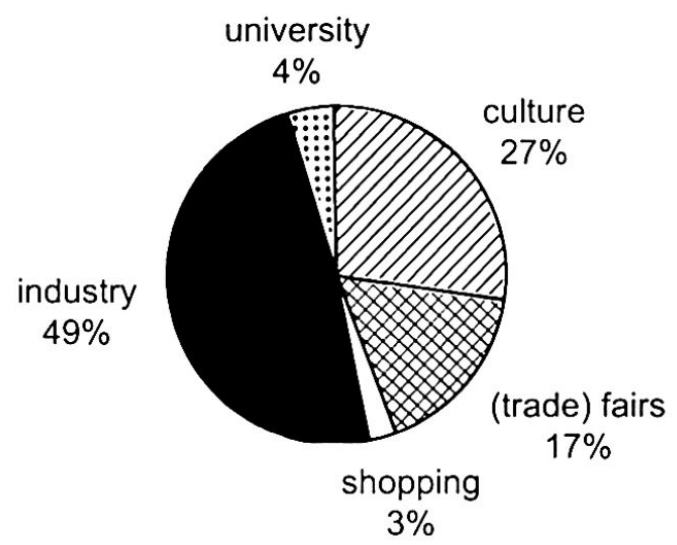

Fig. 4: Key words chosen by tourist subgroups characterizing Basle

Schlagworte der touristischen Teilgruppen Mot clé des sous-groupes de touristes

(Source: Kampschulte \& Schneider-Sliwa 1999: 89) 
- Large sectors of the population and the tourists consider Basle narrow-minded. Based on Basle's longstanding humanistic tradition the city could develop more strongly its liberal-minded, urban, modern and self-confident city-image.

- Specific political planning activities are needed to establish both a city of culture and of science, and a high standard of living. Leadership within the city government is essential, as modern urban marketing does not (only) entail promotion/ advertising.

- Group-specific needs and interests must be the priority of public administration, concerning all planning activities.

\subsection{Key words: Basle's strengths show weaknesses}

Tourists had less trouble finding a suitable title for Basle, while residents failed to decide. Their image of the city rests on three supporting pillars: city of fairs $(36 \%)$, cultural city $(26 \%)$ and industrial city $(25 \%)$. Fewer people consider Basle a university city $(7 \%)$, a shopping city $(6 \%)$ or a sports city (1\%) (Fig. 3 ). The ranking reflects the current urban policy, supporting the city of fairs and partly neglecting the cultural city. The significance of Basle as an industrial city is indisputable, but the association is not necessarily positive. Despite the applied work of the university, its social implication remains barely recognized by the public. The potential of the university remains obviously unexplored. Although sport is of high local importance, success in the international sport's scene is lacking, thus preventing sport from becoming an image factor. Shopping in Basle lacks attractiveness with regard to shopping atmosphere and the assortment structure. Exclusive and attractive pedestrian zones are non-existent, with the shopping situation in lower Basle demanding immediate attention.

Fifty percent of the tourists consider Basle a cultural city. This observation correlates with the publicity slogan of the Basle Tourism Board: «Basle - culture based on tradition». Although $34 \%$ of those interviewed were «fair « visitors, the title «city of fairs» was selected by only $18 \%$ (see above). The youth associate themselves neither with fairs nor with the «art fair» in Basle. Tourists are less aware of the role of industry in Basle (8\%), but recognize the significance of the university above that of the locals $(16 \%)$. The shopping city is more relevant to tourists as to locals (8\%) while the sports' city is not recognized at all (Fig. 3).

The choice of title by the locals is personal and agespecific, whereas for tourists, the visiting motive is decisive. Differences between districts in Basle are the result of diverging social-economic structures. Academics, the elderly and upper class Swiss residing in the district of St. Alban consider Basle primarily a cultural city $(44 \%)$. Numerous museums, galleries and historic buildings located in this district make the association even more obvious. Gundeldingen, a multicultural dis- trict with high proportions of students and young people considers Basle primarily a city of fairs (42\%). St. Alban residents support the notion of a university city with $19 \%$, while Gundeldingen lags behind with $7 \%$. The differences in income and education as well as the perception of one's own district have a distinctive effect on the city-image.

The choice of title is also a result of age-specific interests and situations. The shopping and sports' city Basle is of irreplaceable importance for the younger generation. The high percentage of the shopping city (50\%) among those interviewed under 16 years of age expresses the reality of consume for teenagers. The same applies to young tourists. The older generation in Basle considers Basle a city of fairs.

The higher the education, the greater the importance attributed to the cultural and industrial cities. Those with a lower level of education believe in the city of fairs, shopping and sports. University graduates mention, for example, the cultural city more often than the city of fairs.

The preference of title as selected by the tourist subgroups differs decisively. While city tourists $(52 \%)$ and fair visitors $(56 \%)$ consider Basle a cultural city, congress participants favor the notion of the industrial city (Fig. 4). The image depends on the individual context of persons surveyed. For example, participants of a chemistry congress naturally associate Basle with its function as chemical industrial area. Despite the number of academics (90\%) among the congress visitors and their intensive co-operation with industry, congress visitors barely recognize the university (4\%). Limited co-operation between university and convention center and chemical industry respectively, is observed. Nevertheless, the foreign image of the university $(16 \%)$ is much better than the personal one (7\%). It is nearly equivalent to the city of fairs. Not only the humanistic tradition, but also famous public figures and scientists (among them several Nobel prizewinners), who are in contact with the university enable her an outwardly high prestige.

Compared to local residents city tourists (including shopping tourists from the border regions) consider shopping in Basle more important (11\%). However, neither visitors nor residents really consider Basle a shopping city. The needs and desires of the educated and upper class are not satisfied, and the frequency of visits to Basle does not affect the factor of shopping.

To sum up, city tourists consider Basle a cultural- and university city; congress visitors consider her an industrial city; and fair visitors consider her a cultural city and city of fairs. Frequent visits to Basle decrease the importance of the cultural city insignificantly, but increase the interest of the city of fairs. Many tourists return to Basle to visit trade fairs, including $72 \%$ of previous fair visitors. 


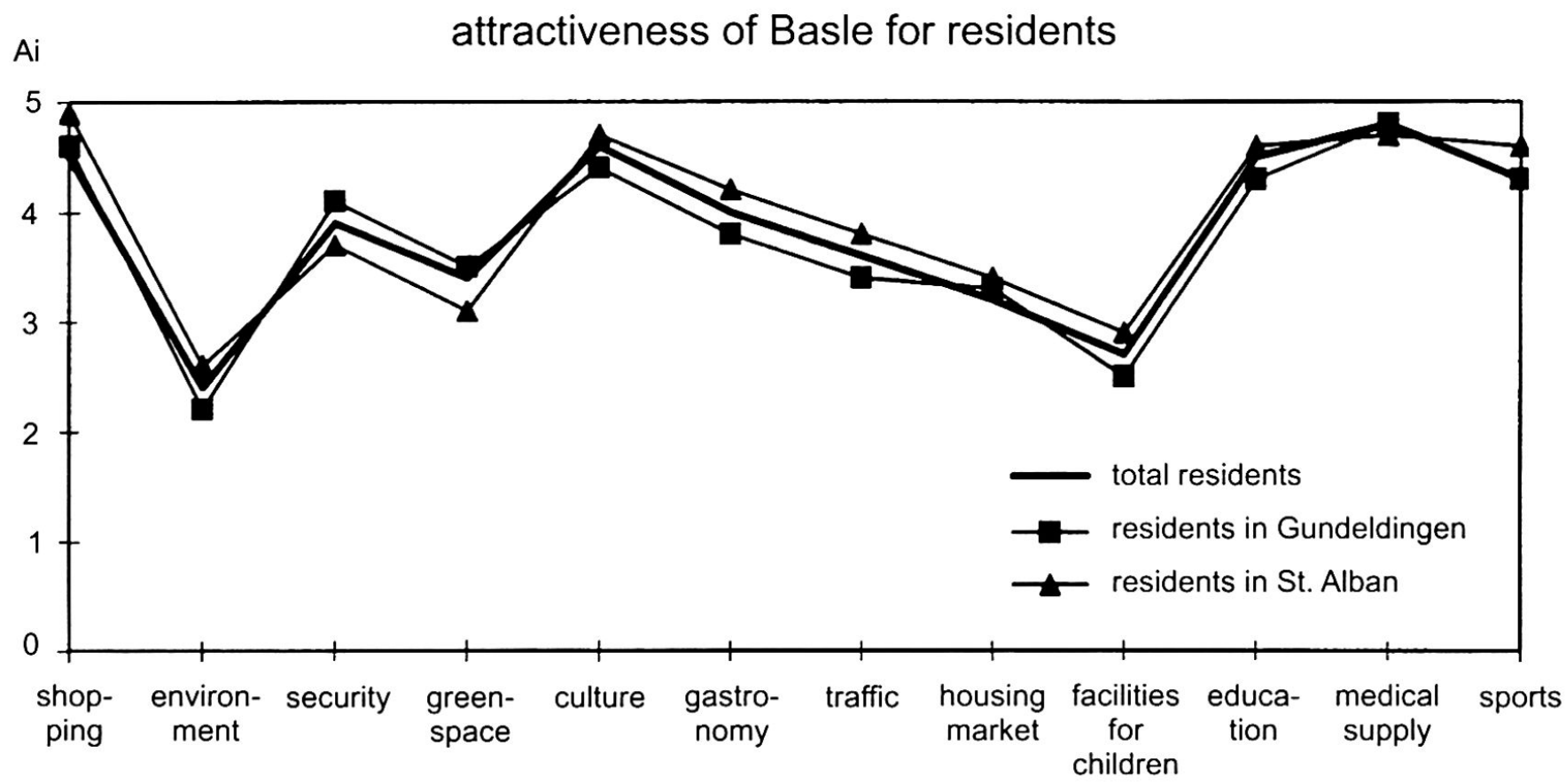

Fig. 5: Attractiveness of Basle for residents Attraktivität Basels für die Wohnbevölkerung Attractivité de Bâle pour la population résidente

(Source: Kampschulte \& SChneider-Sliwa 1999: 115, Tab. A7)

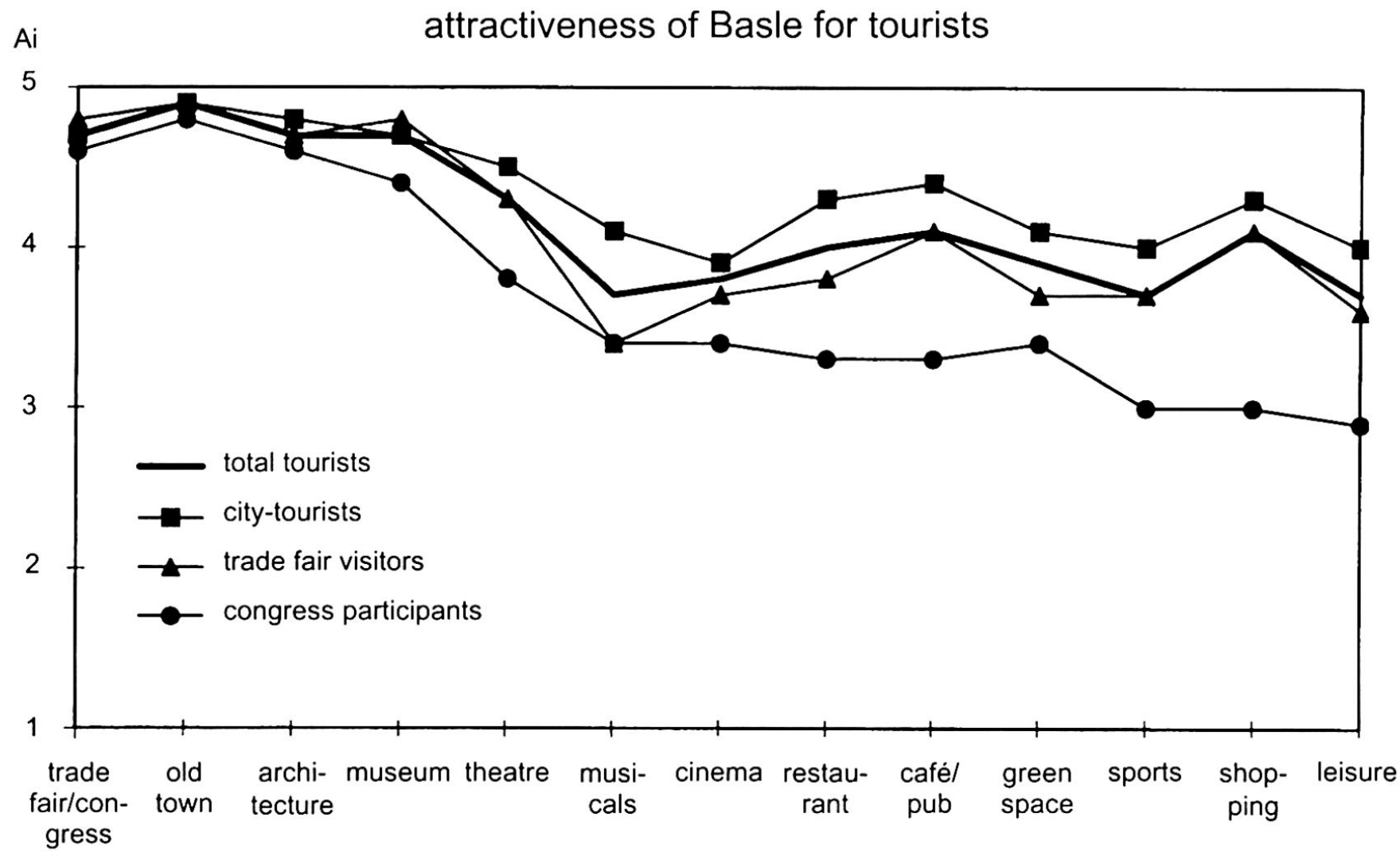

Fig. 6: Attractiveness of Basle for tourists and tourist subgroups Attraktivität Basels für Touristen und touristische Teilgruppen Attractivité de Bâle pour les touristes et les sous-groupes de touristes (Source: Kampschulte \& SchneIder-Sliwa 1999: 92) 
The research results allow the formulation of clear conclusions:

- The image factors «university» and «shopping» both demand target-orientated promotion in order to exhaust hidden potential.

- The university should be integrated into the image of the city. Locals should be made aware of the work and relevance of the university. The city obviously does not recognize available strengths.

- Aims of the shopping city Basle are: increased attractiveness in lower and upper Basle (shopping atmosphere, assortment structure, supply variety, pedestrian zones) and improved purchasing power across the border (the higher prices guarantee essential obstacles that should be counteracted by exclusiveness and «shopping experience»)

- The pillar «trade fair» should be extended to ensure regularity/ continuity of fair visitors

- Marketing is a result of the needs and desires of stakeholders. Special target groups include the youth, congress visitors and educated people. Congress visitors are to be encouraged as they stay longer (5 days) and are the highest percentage of people who do not plan on visiting Basle again (15\%!). Including all persons interviewed, only $4 \%$ would never return to Basle.

\subsection{Attractiveness of Basle:}

\section{Foreign image is better than personal image}

The attractiveness of Basle is characterized by varying forms of attraction, such as shopping, environment, security, green space, culture, gastronomy, traffic, housing market, facilities for children, education, medical supply and sports facilities. The image of the city has been analyzed according to the different criteria of attractiveness.

According to the residents, Basle is a city of poor environmental quality and is neither child-orientated nor child-friendly. The housing market, traffic and green space are unsatisfactory too. These evaluations are based on objective existing deficiencies. The above mentioned factors are essential for living, causing people to leave the city. The upper class and younger families move to surrounding areas in expression of their discontentment. Concrete action needs to be taken.

The unsatisfactory criteria are perceived by all groups of the population. Those under 35 years are especially discontent while youth under 16 years show an extremely negative attitude toward sport, cultural activity opportunities and facilities for children. The age-specific needs and desires are obviously not met. Those over 65 years rate the green spaces, housing market and facilities for children higher. Differing needs and disinterest result in varied evaluation. Personal circumstances strongly influence one's evaluation. The overall evalua- tion of the criteria was more positively assessed in St. Alban than in Gundeldingen (Fig. 5). Factors concerning the elderly, such as green spaces and security fared poorly. The insufficient number of playgrounds and day nurseries is criticized more often in Gundeldingen, as more families live there.

The survey proves the foreign image to be better than the personal image. Tourists evaluate the attractiveness of Basle with another set of criteria. Suggestions have been made concerning the musical theatre, sport opportunities, cinema and diverse green areas. Most of the criteria were positively evaluated: the Old Town (93\%), fairs and congresses $(88 \%)$, museums $(88 \%)$, historical buildings ( $87 \%$ ), theatre and concert (74\%). Every fifth tourist evaluates the musical theatre negatively.

Congress visitors, 25-35 year old persons and educated people are generally more dissatisfied. Due to a limited activity area (surrounding of convention center in lower Basle) the evaluation of congress visitors differs considerably from that of other subgroups. In comparison to the city, this area is less attractive, as it has much traffic, high density of buildings and industrial areas. The gastronomy and retail sectors are lacking, not meeting the higher demands of this subgroup. The city tourists appear to be the most content (Fig. 6).

Age-specific differences refer to the evaluation of culture- and leisure-time-orientated opportunities in the city. Young tourists enjoy age-specific attractions such as cinema, sport and shopping, while the Old Town, museums and theatres are better evaluated by the older one. Tourists over 65 years evaluate restaurants, cafes and parks above average. Highly educated persons evaluate criteria such as theatre, musical theatre, cinema, restaurant, cafes, sports and shopping progressively worse. The frequency of visits has not been taken into account.

The assessment of characteristic features of Basle highlights the difference between foreign and personal interest; (Fig. 7) although the majority of both groups (tourist and resident) characterize Basle as beautiful, interesting and clean, as well as narrow-minded and expensive. Positive characteristics are generally estimated higher by tourists, with the exception of the price structure. $95 \%$ of the tourists find Basle too expensive. The fact that $56 \%$ of the residents and $54 \%$ of the tourists characterize Basle as narrow-minded hints at an insufficient imparting of the humanistic tradition. The poor self-image of Basle as shopping center is consequently related to the high price level. This is confirmed by the extent of losses of purchasing power to Germany and France.

Differences between the urban districts are expressed as «liberal-minded» and «interesting». In Gundeldingen, $36 \%$ of the residents describe Basle as narrow-minded and $59 \%$ as interesting, whereas in St. Alban the corresponding percentages were $12 \%$ and $34 \%$ higher, respectively. This correlates with the good evaluation of 


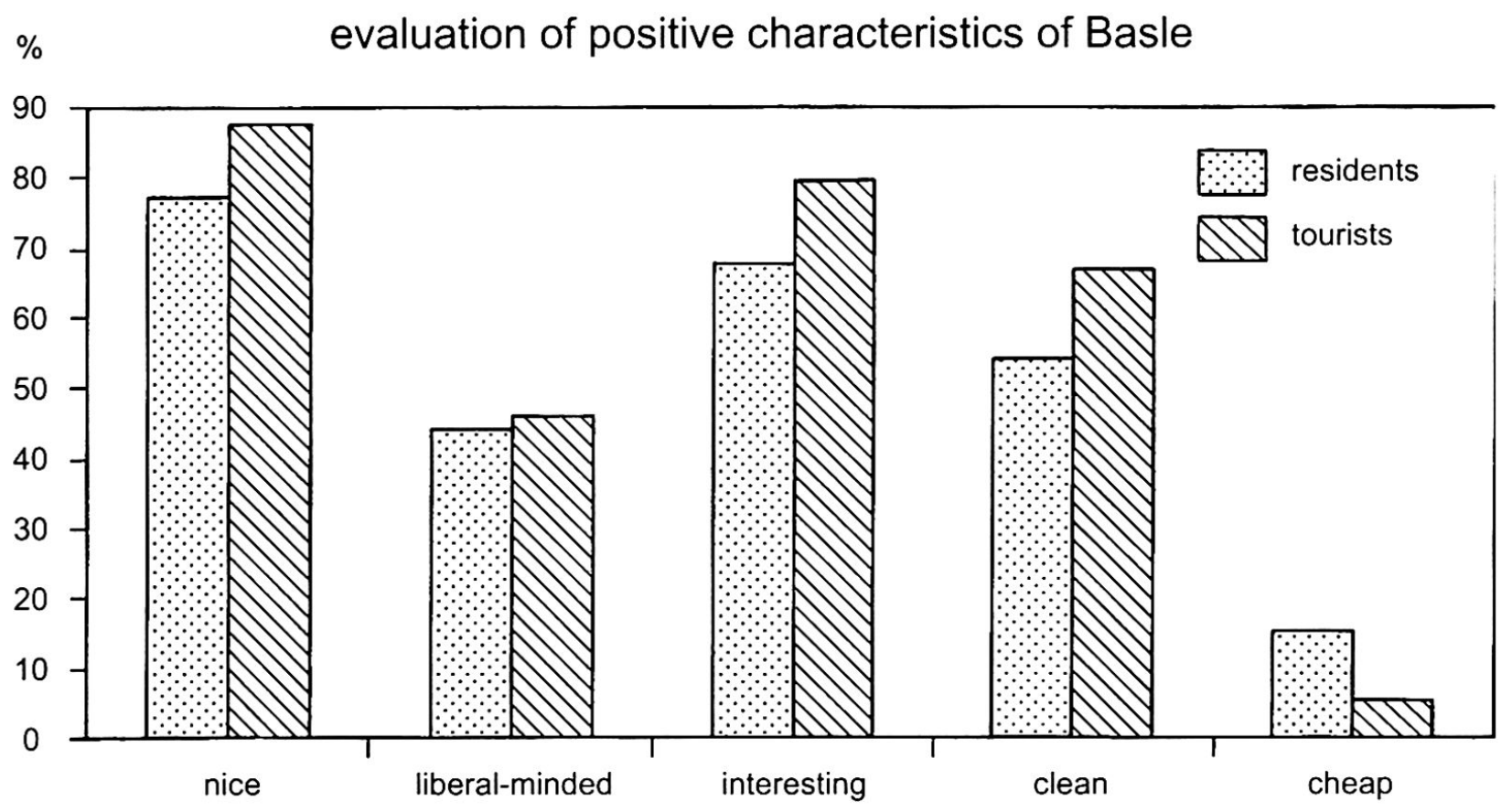

Fig. 7: Positive characteristic features of Basle

Positive charakteristische Eigenschaften Basels

Atouts propres de Bâle

(Source: KampSChUlte \& SCHNEIDER-SLIWA 1999: 99)

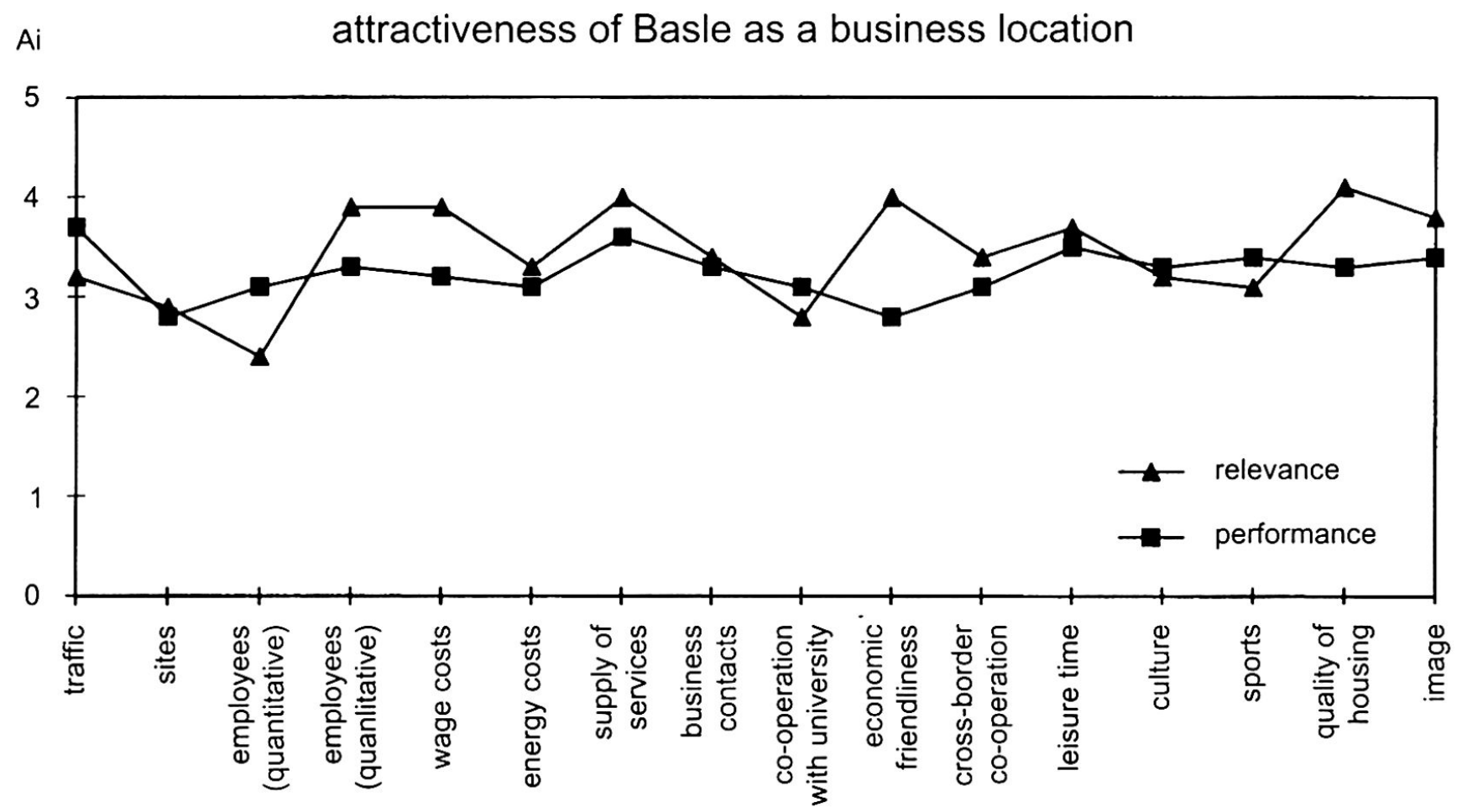

Fig. 8: Attractiveness of Basle as business location: relevance and performance of selected locational factors Attraktivität Basels als Unternehmensstandort: Bedeutung und Erfïllung ausgewählter Standortfaktoren Attractivité de Bâle comme lieu d'implantation d'entreprises: présentation d'importants facteurs propices à l'établissement

(Source: (Source: KampSChUlTE \& SCHNEIDER-SLIWA 1999: 66) 
the attractiveness of culture, gastronomy, education and sports and with that of the cultural and university city in St. Alban. The older the resident, the more positive the response. Emotional aspects may cause a less critical view of the city. The same goes for the time of residence. People living for more than 40 years in Basle identify better with their district and their city respectively. The evaluation continuously improves.

Within the tourist subgroups, $37 \%$ of the congress visitors and $26 \%$ of the persons aged between 25 and 35 years experienced Basle as boring. This responds with the negative evaluation of the criteria of attractiveness in this age group. Frequent visits result in Basle being referred to as liberal-minded, cheap and interesting, but also as dirty. Growing familiarity with the city and the contact to the locals rises with the number of visits, leading to a greater liberalmindedness.

The following measures should be taken to improve the foreign image and especially the personal image:

- Urban marketing should aim to increase urban character and the quality of housing and living. Deficits in the urban housing market do not pertain to the number of houses and flats, but rather to their insufficient size and high price.

- An integral concept for environment and traffic should be developed, taking into consideration real costs. A green- and open-space concept encompassing the whole city is lacking. This concept continues to gain importance, as the ideal living conception in an urban setting tends to demand a green surrounding.

- The opinion of congress- and fair visitors about Basle is important for the foreign image of the city. The needs of these groups need to be addressed, including the improvement of the surroundings of the fair- and convention center.

- Liberalmindedness is important for the quality/ feeling of life the city offers the residents, as well as for the international image she offers her tourists. Being a border town, Basle relies on a successful transborder co-operation. In addition, globalization demands transnational and transregional thinking and acting, being increasingly open-minded toward innovations. A target-orientated, modern marketing of a liberalminded society, backed by humanistic tradition is required. The tri-national location and multicultural character of the city should be integrated more efficiently.

- The needs of children and elderly concerning the design of urban space should be considered as well as the needs of parents/mothers concerning facilities for their children.

- The survey reveals the important effect personal housing and living conditions have on the image. Dissatisfaction for certain things is not shared by all. The older generation has, for example, a more positive image of the city than the younger generation (those $<35$ years). Measures concerning the needs of those $<35$ years, tourists between 25 and 35 years, the fairand congress visitors and highly educated people should be taken.

\subsection{Attractiveness of Basle as location for young entrepreneurs}

The survey reveals where need for action exists to improve the local attractiveness of Basle for young entrepreneurs. The economic policy and urban planning should take into consideration the needs of small and medium-sized enterprises. In contrast to «global players", smaller enterprises are deeply rooted in the region. The quality of housing is the most important local factor for young entrepreneurs (42\% very important). This point especially makes a high discrepancy between importance and fulfillment (Fig. 8).

The need of improvement fits with that of the residents. Further deficits can be recognized according to the supply of services, the economic friendliness, the salary and the qualitative labor shortage. The latter presents a real challenge to the university and educational systems. Local factors with the most negative evaluation are the economic friendliness ( $36 \%$ very bad), the range of sites (29\%) and the wage and energy costs (19\%). The image value of the location is important for $65 \%$ of the young entrepreneurs. Only $44 \%$ think that this factor is fulfilled at the location of Basle. In comparison to residents and tourists, the young entrepreneurs have the most negative image of Basle. This shows that the image of the city needs special improvement.

\section{Conclusion}

The image analysis is a marketing instrument capable of steering the future course of urban development. It is a seismograph of the development potential of Basle and facilitates «new public management» (control mechanism). It forms the basis of target-orientated action toward the realization of the vision of the image. A comprehensive urban marketing strategy must be based on a holistic approach, a long-term vision and clear development goal that takes all stakeholders into consideration. Local initiative, leadership and planning to increase the attractiveness and to stress the local uniqueness and peculiarities are necessary to stand up against global competition.

Generally speaking, as far as the residents and tourists are concerned, the image of Basle is positive. Dissatisfaction among definite groups of residents and tourists and the negative evaluation of single image factors, nevertheless, hint at a need for action in certain areas in order to improve the general impression. The dissatisfaction is caused mainly by a discrepancy between plan- 
ning on the one hand and the needs of diverse groups on the other hand. General statements concerning unused potential, possible solutions for image problems and concrete recommendations for action can be derived from the results of the survey presented.

\section{Literature Cited}

BERTRAM, M. (1995): Marketing für Städte und Regionen - Modeerscheinung oder Schlüssel zur dauerhaften Entwicklung. - In: BEYER, R. \& I. KURON (Hrsg.): Stadt- und Regionalmarketing - Irrweg oder Stein der Weisen? - = Material zur Angewandten Geographie 29, Bonn: 29-38.

Beyrow, M. (1998): Mut zum Profil. Corporate Identity und Corporate Design für Städte. - Stuttgart: avedition. BORCHERT, J.G. (1994): Urban Marketing: A Review. In: Braun, G.O. (ed.): Managing and Marketing of Urban Development and Urban Life. $-=$ Abhandlungen Anthropogeographie, Institut für Geographische Wissenschaften, FU Berlin 52, Berlin: 415-427.

DudE, E. (1989): Blühender Handel - lebendige Innenstadt. - In: Deutscher Industrie- UND HANDELSTAG (Hrsg.): Modernes Stadtmarketing. - Bonn: 1-61.

Frey, R. \& S. Schaltegger (1999): Städte im Standortwettbewerb. Probleme und künftige Entwicklungen. $-=$ Vortrag am Forum für Raumordnung des ORLInstituts, ETH Zürich, 16. März 1999, Basel: 1-7.

FUNKE, U. (1994): Vom Stadtmarketing zur Stadtkonzeption. $-=$ Neue Schriften des Deutschen Städtetages 68, Stuttgart: 1-133.

Grabow, B. (1998): Stadtmarketing - eine kritische Zwischenbilanz. - In: Difu-Berichte 1/1998: 2-5.

HäussermanN, H. \& W. Siebel (1992): Urbanität als Lebensweise. Zur Kritik der Ausstattungskultur. - In: Informationen zur Raumentwicklung 1, Bonn: 29-35.

Helbrecht, I. (1994): «Stadtmarketing»: Konturen einer kommunikativen Stadtentwicklungspolitik. - = Stadtforschung aktuell 44, Basel, Boston, Berlin: 1249.

Kampschulte, A. \& R. Schneider-Sliwa (1999): Das Image von Basel - Steuerungsinstrument für die Stadtentwicklung? - = Basler Feldbuch 16, Beiträge zur Stadt- und Regionalforschung, Basel: 1-125.

Konken, M. (1996): Stadtmarketing. Eine Vision wird Realität. - Limburgerhof: FBV Medien-Verlag.

Kotler, P., Haider, D. \& I. Rein (1994): StandortMarketing. Wie Städte, Regionen und Länder gezielt Investitionen, Industrien und Tourismus anziehen. Düsseldorf, Wien, New York, Moskau: ECON Verlag. KRÄTKE, S. (1995): Stadt - Raum - Ökonomie. Einführung in aktuelle Problemfelder der Stadtökonomie und Wirtschaftsgeographie. - = Stadtforschung aktuell 53, Basel: 1-261.

Kuron, I. (1997): Stadtmarketing: Chance zur ganzheitlichen Stadtentwicklung. - In: PFAFF-SChlEy, H. (Hrsg.): Stadtmarketing und kommunales Audit. Chan- ce für eine ganzheitliche Stadtentwicklung. - Berlin, Heidelberg, New York: 1-13.

Meissner, H.G. (1995): Stadtmarketing - Eine Einführung. - In: BEYER, R. \& I. KURON (Hrsg.): Stadtund Regionalmarketing - Irrweg oder Stein der Weisen? - = Material zur Angewandten Geographie 29, Bonn: 21-27.

MüLLER, W.H. (1992): Territoriales (regionales und kommunales) Marketing. - = Wibera-Sonderdruck 223, Düsseldorf: 1-18.

SPIEgEL, R. (1961): Die Struktur der Meinungsverteilung im sozialen Feld. Das psychologische Marktmodell. - Bern, Stuttgart: Hans Huber.

TRIEB, M. (1974): Stadtgestaltung. Theorie und Praxis. - Düsseldorf: Bertelsmann.

\section{Summary: «Image» as an instrument of urban management}

Globalization and competition between cities require a new kind of planning policy. An urban development policy, which promotes a city's attractiveness for visitors and local enterprises as well as for residents is necessary in order to profitably sell the product «city». Therefore, urban marketing is not only a public relations campaign to attract tourists and investors, but a market oriented urban development policy. This should take into account the interests and needs of all of the city's customers. All target groups should take an active part in a common vision of the future development of Basle. Regarding this, the image analysis identifies a need for action. In the perception of many people Basle lacks a clear profile. Important image factors show weaknesses, and group-specific needs are partly neglected. Especially the identification with the city and a target-oriented marketing of specific attractions should be specifically promoted.

\section{Zusammenfassung: «Image» als ein Instrument marktorientierter Stadtentwicklungspolitik}

Globalisierung und veränderte Wettbewerbsbedingungen stellen neue Anforderungen an die Planungspolitik. Um das Produkt «Stadt» auf dem Markt zu platzieren, bedarf es einer Stadtentwicklungspolitik, die gleichermassen ihre Attraktivität als Wohn- und Lebensraum, als Fremdenverkehrsort und als Wirtschaftsstandort fördert. Stadtmarketing ist daher nicht nur als Werbemassnahme zur Anziehung von Touristen und Investoren zu verstehen, sondern als eine Stadtentwicklungspolitik, die sich «am Markt», d.h. an den Interessen und Bedürfnissen aller Anspruchsgruppen orientiert und diese aktiv in eine gemeinsam getragene Vision der zukünftigen Stadt Basel einbindet. Die Imageanalyse zeigt, dass diesbezüglich in Basel ein deutlicher Handlungsbedarf besteht. In der Wahrnehmung Vieler fehlt der Stadt ein klares Profil, weisen wesentliche Imagefaktoren Schwächen auf und werden die Bedürfnisse der ver- 
schiedenen Anspruchsgruppen nicht ausreichend berücksichtigt. Insbesondere gilt es die Identifikation mit der Stadt und die Ortsgebundenheit zu fördern sowie das Ortsspezifische gezielter zu vermarkten.

\section{Résumé : L'«image» en tant qu'instrument d'une politique de développement urbain axée sur le marché}

Le phénomène de la globalisation et l'intensification de la concurrence imposent de nouvelles exigences à la planification urbaine. En effet, positionner sur le marché le produit «ville» nécessite aujourd'hui une politique active du développement urbain dans différents secteurs: le logement, l'espace vital, le tourisme, la place économique. Le marketing d'une ville est par conséquent bien plus qu'une démarche promotionnelle pour attirer les touristes et les investisseurs: c'est au contraire une politique de développement urbain axée sur le «marché», qui tient compte des intérêts et des besoins de tous les groupes en présence pour promouvoir activement une vision commune du Bâle de demain. L'étude menée révèle qu'un important besoin d'action existe. Car aux yeux de beaucoup de gens, le profil de la ville est imprécis, des facteurs d'images essentiels présentent des faiblesses et les besoins des divers groupes en présence ne sont pas suffisamment pris en considération.
Il s'agit en particulier, d'une part, de renforcer le réflexe identitaire des Bâlois et leur attachement à leur ville, et d'autre part, de commercialiser de manière plus ciblée les produits spécifiques de Bâle.

Dr. phil. Andrea Kampschulte, Abteilung Humangeographie/Stadt- und Regionalforschung, Departement Geographie, Universität Basel, Klingelbergstrasse 16, $\mathrm{CH}-4056$ Basel.

e-mail: andrea.kampschulte@unibas.ch

Manuskripteingang/received/rentrée du manuscrit: 27.9.1999

Annahme zum Druck/Accepted for publication/ acceptation à l'impression: 15.1.2000 